\title{
Nishimura Masanari's Study of the Earliest Known Shipwreck Found in Vietnam
}

\author{
Nishino Noriko \\ Foundation to Safeguard the Underground Cultural Heritage in Southeast Asia, \\ Japan \\ norikonishino@gmail.com \\ Aoyama Toru \\ Tokyo University of Foreign Studies, Japan \\ taoyama@tufs.ac.jp \\ KimuraJun \\ Tokai University, Japan \\ junkimura@tsc.u-tokai.ac.jp \\ Nogami Takenori \\ Nagasaki University, Japan \\ nogami.takenori@gmail.com \\ Le Thi Lien \\ Vietnam Academy of Social Sciences \\ lelien_thi@hotmail.com
}

\begin{abstract}
The Chau Tan shipwreck, probably the earliest shipwreck in Vietnam, was found in the waters off the shore of Binh Son District in Quang Ngai Province in the early 2000 . Dr. Nishimura initiated a study of the shipwreck material, but it was cut short by his sudden demise. A group of Japanese scholars continued the project in co-operation with the Institute of Archaeology (Vietnam). Since remnants of the shipwreck were pillaged and their archaeological contexts were not recorded, this initial study is limited to a comparative assessment of the recovered items, including wooden timbers from the hull and Chinese ceramics. It is also a case study for addressing the ethical issues of raising shipwreck remains in Vietnam for commercial purposes without conducting scientific surveys. The study indicates that the ship timbers came from an eighth-ninth
\end{abstract}


century Southeast Asian ship, and that the Chinese ceramics can be assigned to the Tang Dynasty. A number of inked or inscribed characters on ceramic shards indicate the involvement of Indian Ocean merchants.

\section{Keywords}

Arabic and Indic scripts - ceramic study - maritime archaeology - Maritime Silk Route - shipwreck - Vietnam

\section{Introduction}

The discovery of three shipwrecks in the waters off the shore of Binh Son District in Quang Ngai Province in Vietnam was reported in the early 2000 s. These shipwrecks include the Binh Chau No. 1, Binh Chau No. 2, and Chau Tan shipwrecks. While the first two have been excavated by local municipality offices, the circumstances of the recovery of the Chau Tan shipwreck material are not entirely clear.

Dr. Nishimura Masanari initiated the study of the Chau Tan shipwreck material and the area where it was found, namely the waters off the beach of Chau Tan village, Binh Son District, Quang Ngai Province, Central Vietnam (Fig. 1). He thought that the remains might include cargo from one or more shipwrecks and might even turn out to represent one of the earliest shipwrecks so far discovered in Vietnam (perhaps even in the waters of the entire Southeast Asian region). Even though the well-preserved nature of the remains and the hull was apparent, the wreck site was abandoned after salvage operations, as was the case with other shipwrecks in Vietnam. ${ }^{1}$ Despite its historical importance, no site mitigation plans or strategies to protect and manage the shipwreck as an archaeological and underwater cultural heritage site were developed.

For the convenience of researchers, Dr. Nishimura designated the artifacts recovered from the wreck as the Chau Tan shipwreck material. Most of the salvaged artifacts are currently in the home of a private collector in Binh Son District. Considerable ethical issues surround the material salvaged from the Chau Tan shipwreck, and there is an inherent bias against the study of the remains. Acknowledging these limitations, the authors note the importance of promoting increased awareness of the need to safeguard shipwrecks as

\footnotetext{
1 Michael Flecker, "Excavation of an Oriental Vessel of c. 1690 off Con Dao, Vietnam," International Journal of Nautical Archaeology 21, no. 3 (1992): 221-244.
} 


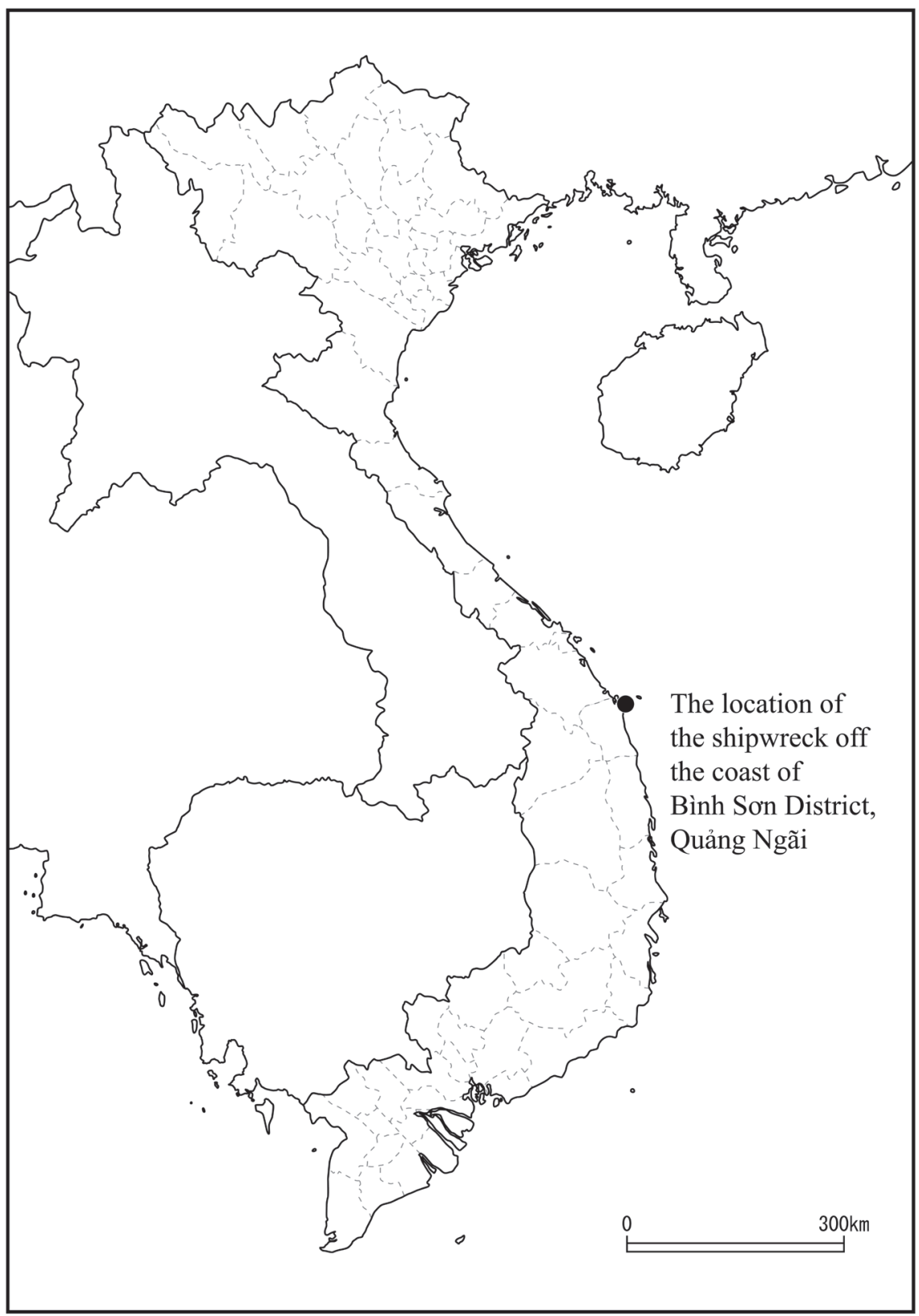

FIGURE 1 Location of the Chau Tan shipwreck. Map constructed based on CraftMAP. 
archaeological sites in Vietnam and demonstrate some approaches relevant to the study of a historical shipwreck.

\section{Background of the Nishimura Project}

The importance of the material recovered from the waters off a beach alongside Chau Tan village was first recognized by Dr. Nishimura in the early 2000 . The beach is a small part of a long, curving sandy shore in Binh Son District, located between capes to the north and south and projecting a long way into the sea. The waters off the beach are relatively shallow and are punctuated by the small island of Ly Son, possibly once a landmark for sailors. The place is known as "Vung Tau" (anchorage), but it consists of rocky seabed where ships are locked in, and many ships are said to have been lost in this hazardous area.

Nishimura identified the recovered artifacts - which include trade ceramics from the ninth century, some bearing incised Chinese inscriptions and Chinese and Indic calligraphic ink inscriptions_-as the cargo of a lost ship. The ceramics were considered to be especially significant as a primary source for understanding ninth-century trade through preliminary epigraphic study of the incised and ink inscriptions, provenance study to determine where the ceramics were produced, and comparison with ceramics excavated at other sites in the region. Nishimura aimed to clarify the historical value of the shipwreck artifacts as a key resource for the study of ninth-century maritime trade based on a comprehensive understanding of the ship, including the trading system in which it functioned and its origin and destination.

Nishimura had to confront considerable issues concerning the archaeological value of the artifacts from the Chau Tan shipwreck. Almost no archaeological information is available about the location or extent of the wreck site, and it is not clear whether the material originated from a single shipwreck or multiple shipwrecks - a critical problem for interpretation of the remains. In addition, due to the site's shallow waters and its reputation as a hazardous area for sailing vessels, the recovered artifacts could have been contaminated by items from later periods. Finally, the remains of the ship itself have been heavily damaged by pillaging. Considering the circumstances, Nishimura developed a research program to evaluate the condition of the shipwreck remains and to determine how the ship was sunk and the site was formed. At the same time, he approached a private collector who owns most of the recovered artifacts, in the hope of negotiating an arrangement that would prevent them from being scattered and lost. The collector said that they had been salvaged from a single wreck near Chau Tan village. Because the historical value of the recovered 
artifacts - which mostly consist of some intact ceramics and many shardswas clearly evident, they were initially placed in approximately four hundred sandbags to be preserved for academic study as the Chau Tan shipwreck collection.

Between 2011 and 2013 Nishimura made several trips to Quang Ngai Province, conducting a typological analysis, reconstructing the assemblage of ceramics, and making a detailed classification of all the artifacts in order to determine the composition of the cargo of the ship (or ships). Hoping to raise awareness of the importance of shipwreck sites and their associated artifacts, Nishimura included among his broader research objectives an evaluation of the Chau Tan shipwreck material in terms of its potential as an anchoring collection for a future maritime culture museum or resource center.

Work ceased for a time following Nishimura's death after his final field trip to Quang Ngai in May 2013. In 2014 the authors of this article decided to take over, motivated by an appreciation of the historical value of the Chau Tan shipwreck and by Nishimura's own dedication and achievements. Their decision to pursue the study of the Chau Tan shipwreck coincided with the growth of Vietnamese maritime archaeology, as reflected in the establishment in July 2013 of the Department of Underwater Archaeology under the Institute of Archaeology of the Vietnamese Academy for Social Science. Despite ethical concerns surrounding commercial salvage operations at the Chau Tan site and ongoing pillaging off the coast of Quang Ngai Province, the authors believe that follow-up analysis of the recovered timbers and artifacts contributes to capacity building in Vietnamese nautical archaeological studies.

\section{Ship Timbers}

It has been postulated that the techniques used to construct the Chau Tan ship were similar to those used for the Belitung ship. However, our initial investigation shows that the structure of the recovered ship timbers is distinct from that of the Belitung ship, which is an ancestral type of Indian Ocean dhow. ${ }^{2}$ The technology of the ship timbers reflects traditional Southeast Asian shipbuilding technology. The following paragraphs summarize the evidence of construction methods observed during a preliminary recording of the salvaged ship timbers.

2 Nishino Noriko et al., "Nishimura Project: The Oldest Shipwreck found in Vietnam: Testimony to the Maritime Ceramic Route," paper presented at the International Symposium on Underwater Archaeology in Vietnam and Southeast Asia: Potential and Challenged Issues, Quang Ngai City, Quang Ngai, October 14-16, 2014. 
The ship timbers were initially reported to be buried beneath the sandy seabed only 30 meters off the beach next to Chau Tan village. According to a collector of Chau Tan shipwreck material, a large typhoon that struck the Binh Chau coast in 2009 exposed the site, which resulted in the pillaging and salvaging by local people of many artifacts as well as remnants of the hull. No information is available on the amount of ship timbers salvaged from the seabed; however, some were secured and stored by the collector. The salvaged timbers were extensively examined between 2013 and 2016 by the authors in conjunction with staff from the Department of Underwater Archaeology at the Institute of Archaeology. In 2016, the salvage location was identified through interviews with divers who were personally involved in the salvage operations; the position was located with GPS co-ordinates.

The 2014-2016 inspections of the remains of the hull recorded forty-nine timbers, including planks and frames and two timbers that are clearly not hull remains but may belong to wooden anchors (Fig. 2). No preservation treatment was implemented after the salvage. The surface of all the ship timbers was heavily degraded and cracking and shrinkage was evident on almost all planks. The owner is currently attempting to prevent further damage to the timbers by covering them with tarpaulin. Some of the planks were cut during the salvage process; for example, the ship's keel was deliberately dismantled into three pieces so that it could be raised from the seabed and its wood reused in the construction of a building. The total length of the original keel timber is more than 22 meters, which indicates that the original ship may have been nearly 25 meters long. The remains of a half-frame consisting of two pieces provide some clues for estimating the ship's approximate width, which may have been 9 meters or more. The half-frames were mounted on protrusions that were chamfered on the inner surface of the planks. The protrusions have holes through which vegetable fibers passed, holding the frames together. This technique has been described as a lashed-lug construction method, an endemic Southeast Asian shipbuilding technique. ${ }^{3}$ Wooden dowels with an edge-joint were used for the planking of Southeast Asian ships. The Chau Tan ship also used wooden dowels as fasteners, but part of the plank seam appears to have been joined by dowels made of iron. Each strake is composed of two to three planks, and their butts were tightly connected with a hooked-scarf joint.

Although there are some distinctive characteristics in the structure of the ship timbers, overall the timbers belong to a ship built using indigenous Southeast Asian shipbuilding technology. This shipbuilding tradition was widely disseminated over the centuries and is reflected in the construction

3 Sean McGrail, Boats of the World: From the Stone Age to Medieval Times (Oxford: Oxford University Press, 2004). 


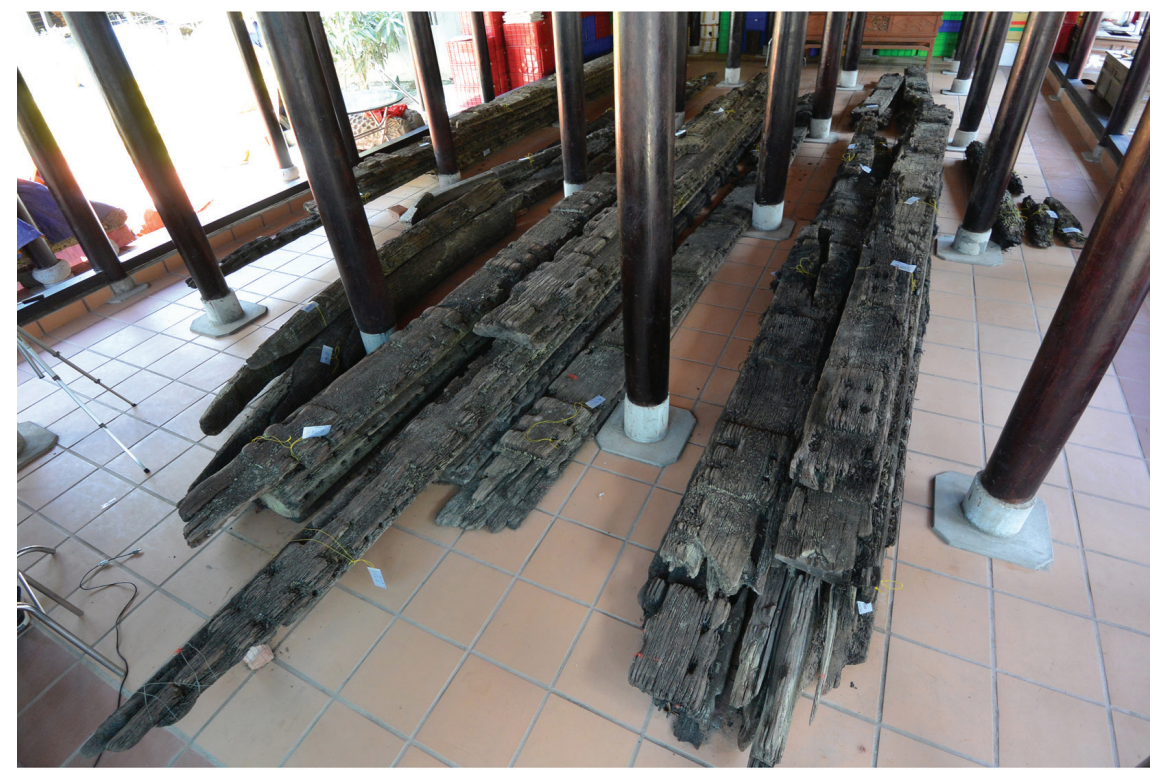

FIGURE 2 Top: Disarticulated hull timbers. Bottom: One of the keel timbers. PHOTO: KIMURA JUN. PHOTO: KEVIN EDWARDS.

of ships excavated in the waters of Island and Mainland Southeast Asia. ${ }^{4}$ Significantly, the Chau Tan ship was the first example of this technology to be identified in Vietnam. In 2014 specimens of the planks were collected for wood species identification and radiocarbon dating. The wood specimen from the keel timber was tested at the AMs radiocarbon dating laboratory at the Paleo Labo Company. The calibration of the resulting AMS radiocarbon age of 1305 \pm 15 years B P corresponds to cal $663-715 \mathrm{CE}$ (at $68.7 \%$ probability) and cal $743-$ $766 \mathrm{CE}$ (at $26.7 \%$ probability), indicating that the keel was cut between the late seventh and mid eighth century. Detailed photos of the ship timbers were taken for the photogrammetric recording and reconstruction of the timbers. These techniques will provide further details about the ship.

4 Kimura Jun, "Seafaring in the Far East," in The World in the Viking Age, eds. Søren M. Sindbæk and Athena Trakadas (Roskilde: Viking Ship Museum, 2014), 119. 


\section{The Salvaged Cargo of the Chau Tan Shipwreck}

Numerous objects have been salvaged in the waters off the long shore of Binh Son District. Salvaged ceramics in a private collection span from the Tang through the Five Dynasties, the Song, the Yuan, the Ming, and the early to mid Qing Dynasty. No archaeological information or records, such as the exact area of salvage operations, are available. However, the recovered objects include a substantial number of the same types of ceramics, and a few piled ceramics are found in concretion with heavily corroded pieces of iron. The assemblage and condition of the ceramics shows that they came from shipwrecks, and some were seaborne trade commodities. Based on the limited information available, it is estimated that these ceramics could have originated from at least six or seven sunken ships or cargos, which indicates that many ships have been entrapped in the waters off the shore of Binh Son District.

The oldest group of ceramics among the salvaged material was produced during the Tang Dynasty and the Five Dynasties. The collector kept these distinctive ceramics, which are said to have been specially salvaged where the ship timbers were found, together in a group. The ceramics have been dated to approximately the ninth century and consist of Yue celadon ware, Changsha celadon and underglaze ceramics made at the kilns of Tongguan, Xing-type white porcelain, and some jars from the Guangdong area. Other distinctive items, such as Three Color Ware and blue and white ware, as well as Islamic green-blue glazed jar shards, were also said to be associated with the ship timbers. These items are of signal importance for the historical study of the shipwreck and will be described in more detail below.

Another large group of salvaged ceramics consists of celadon and white porcelains ranging in time from the Song to the Ming period. The majority are from the kilns of Longquan. These are ceramics from ongoing salvage operations led by the Quang Ngai Provincial Museum. There are some kingfisher blueglazed jars with arabesque patterns in black underglaze, made at the kilns of Cizhou and assigned to the fourteenth-century Yuan Dynasty. Ming Dynasty ceramics include blue and white bowls and dishes produced in the kilns of Jingdezhen in the late sixteenth century. Late sixteenth to early seventeenthcentury Zhangzhou ware is present, including large blue and white dishes and cobalt blue-glazed porcelains with flower designs in white underglaze. The latter are identical to ceramics salvaged from the Binh Thuan shipwreck in Vietnamese waters. ${ }^{5}$

5 See the catalogue prepared by Christie's auction house, The Binh Thuan Shipwreck (N.p.: Christie's Australia, 2004). 
The salvaged ceramics also include some Qing Dynasty ceramics, such as late seventeenth-century blue and white dishes with a leaf design, a typical motif in this period. The Jingdezhen kilns produced porcelains with this motif at that time, as did the Fujian and Guangdong kilns. Some of the ceramics excavated at these kilns and consumption sites on land bear inscriptions of a sixty-year cycle that can be dated to the late seventeenth century: for example, "Bingchen" (1676) and "Dingsi" (1677). ${ }^{6}$ Among the later Qing ceramics, from the eighteenth to early nineteenth century, are blue and white bowls with designs of Indic inscriptions; dishes with arabesque designs; blue and white porcelain with stamp-pattern designs, produced in the Dehua and Fujian kilns; and Guangdong-type ware, including blue and white, blue and white with stamp pattern, and over-glaze enamel dishes.

Apart from ceramics, the private collection mentioned above contains a number of other objects salvaged mostly from the waters off Binh Chau, but the fact that their archaeological contexts were not recorded excludes these nonceramic objects from scientific study. It is likely that some of the recovered artifacts are unrelated to the ceramics and may not have originated from the same source; it is difficult to determine if they derive from shipwreck cargo or are merely abandoned objects. The time periods of the miscellaneous objects appear to vary, but no dating of these objects has yet been attempted. Thus, the assemblage of nonceramic objects does not provide reliable information at this stage.

\section{Artifacts Included in the Chau Tan Shipwreck Material}

As noted above, the quantity of salvaged ceramics assigned to the period between the Tang Dynasty and the Five Dynasties filled four hundred sandbags. Inventory and classification work are still ongoing on two-thirds of the ceramics. Preliminary classification results may yield a profile of the overall assemblage of the salvaged ceramics. According to the collector, other items were salvaged with the ship timbers, including copper alloy objects, copper coins, copper mirrors, stone objects, paper documents, and shell products, but a

6 Nogami Takenori, "Ajia ga hajimetedeatta Arita Yaki” (Encounter of Arita Porcelains in Asia), in Ajia ga Hajimetedeatta Arita Yaki: Gamo Korekushon wo Chuushinni (Encounter of Arita porcelains in Asia: Based on the collection of Gamo), ed. History and Folklore Museum of Arita (Arita: History and Folklore Museum of Arita, 2013). 
detailed examination of these objects is beyond the scope of this preliminary study. The following sections provide an introductory description of some of these objects.

\section{Porcelains and High-Quality Ceramics}

Ceramics make up the largest proportion of objects salvaged from the Chau Tan shipwreck and are mainly Yue ware, Changsha-Tongguan ware, and Xingtype white porcelain.

The Yue ware of the Chau Tan shipwreck material consists of bowls, dishes, small dishes, and ewers (Fig. 3). The majority are bowls with bases of various styles, and these comprise the largest group among the salvaged ceramics. The salvaged Changsha ware includes ewers and bowls with white glaze and decorations of brown and green (Fig. 4). The bowls and dishes show variety in

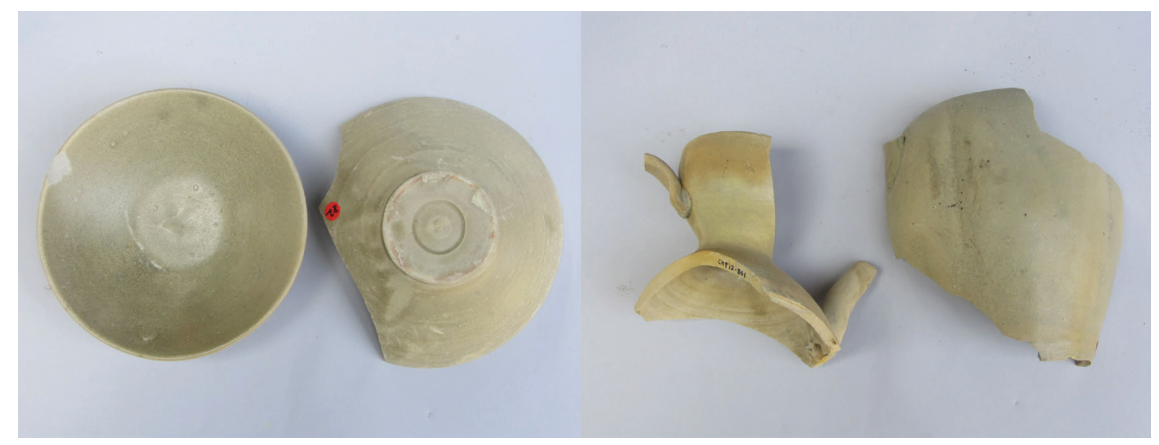

FIGURE 3 Left:Yue bowls. Right: Yue ewers. PHOTOS: NISHINO NORIKO AND NOGAMI TAKENORI.

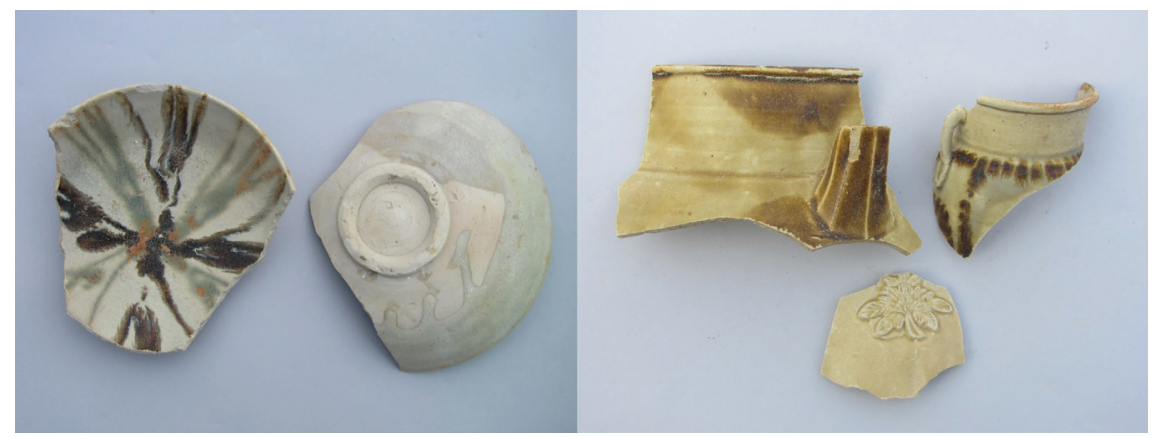

FIGURE 4 Left: Changsha-Tongguan bowls. Right: Changsha-Tongguan ewers. PHOTOS: NISHINO NORIKO AND NOGAMI TAKENORI. 


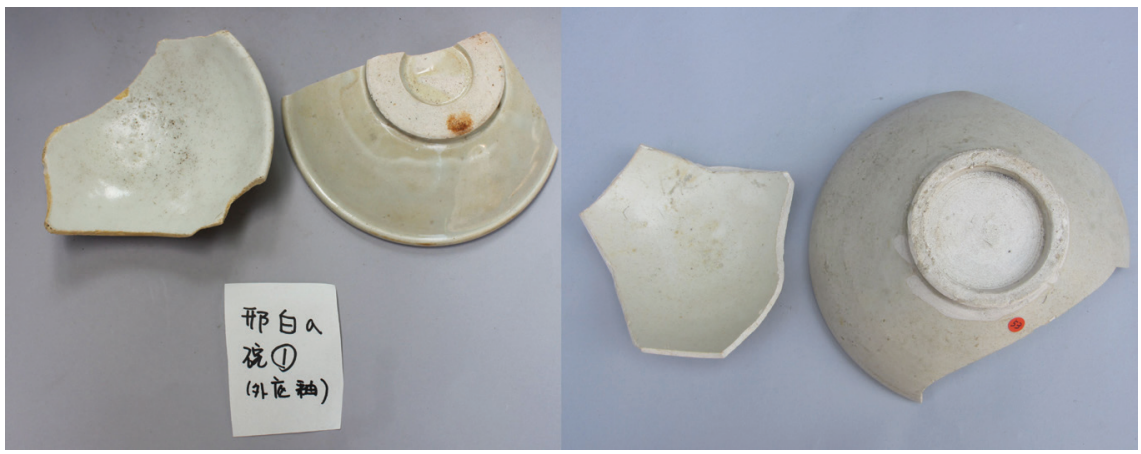

FIGURE 5 Xing bowls.

PHOTOS: NISHINO NORIKO, NOGAMI TAKENORI, AND TANAKA KATSUKO.

shape and rim decoration. Some bear incised Chinese inscriptions: he cha keng (河茶坑) and ban (班).

The Xing pieces are mainly dishes and bowls (Fig. 5). Some bowls have a flat base with a depression at the center and a rimmed edge with a rolled lip.

Other Chinese ceramic types include ewers with a dragon decoration, ash-glazed jars with four handles, six-handle jars, ash-glazed tubs, and grayblack jars and pans (Fig. 6, left). These coarsely made jars were produced in the area of modern Guangdong. Only a small number of gray-black pans have been found. Soot found inside some of them indicates that they were used by sailors for cooking on board. Mortars with an inside decoration of incised lines have also been found, but they do not show any evidence of use, so they may have been trade items. Blue-glazed Islamic jar pieces were also recovered (Fig. 6, right). Some human figures made of lead-glazed ware, the so-called Three Color Ware, are said to belong to the collection.

\section{Copper/Copper Alloy Products, Stone Products, and Documents}

Some metal objects are said to be part of the Chau Tan shipwreck material. The copper alloy products identified include a small hand-mirror, a bowl, and copper coins. A total of fifty-five copper coins are identified as Kaiyuan Tongbao, manufactured mainly by the Tang. There are at least two other coins assigned to different reigns. Inscriptions indicating the regimes are not fully legible, but one can be read as Qianyuan Zhongbao, presumably from the Qianyuan reign $\left(75^{8-760) \text {. }}\right.$

Two ink stones are said to have been recovered, one of which has two feet on the bottom. Other stone products include a plate, hammer, and mortar, perhaps used by sailors on board. 

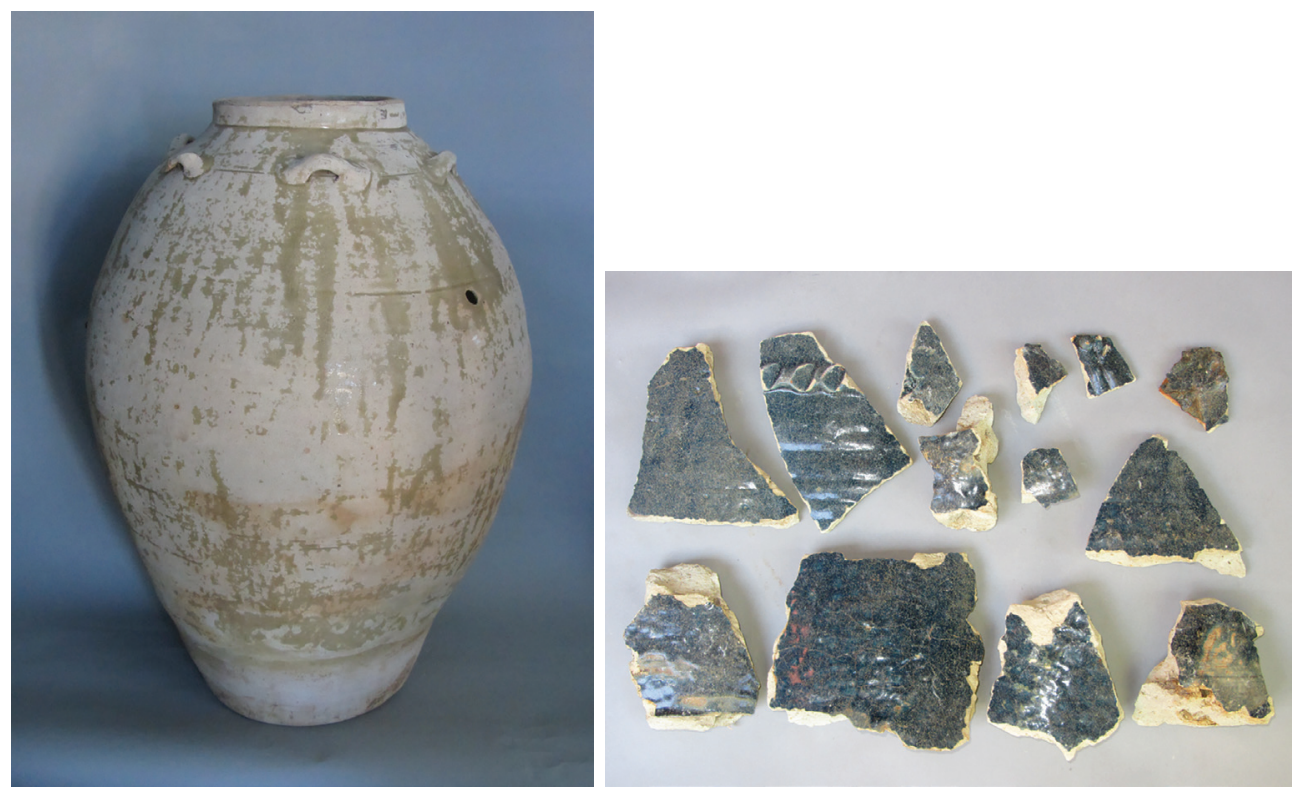

FIGURE 6 Left:Ash-glazed jar with six handles produced in Guangdong. Right: Fragments of Islamic jars. PHOTOS: NISHINO NORIKO AND NOGAMI TAKENORI.

Notably, three thick documents (possibly made of paper) were recovered, but all are heavily degraded. According to the owner of the collection, some of the text was visible when these were recovered from the water.

\section{Inscriptions on the Ceramics}

One noteworthy aspect of the Chau Tan shipwreck material is the set of inscriptions found on the surface of the ceramics. These inscriptions were inspected and photographed in 2014. As the inspection was of a preliminary nature, the numbers given here are tentative and must be treated as such. In this inspection, 585 ceramic shards with inscriptions were identified. The inscriptions may be divided into two types: incised inscriptions and ink inscriptions. The former were incised with a sharp and pointed object before the ceramics were fired in a kiln, while the latter were inscribed with brush and ink at some point after the ceramics were made. A total of 147 shards with incised inscriptions have been identified; they are mainly found on bowls and jars produced in Chinese kilns. Most of the inscriptions are in Chinese characters, but some 
appear to be in pseudo-Arabic script. ${ }^{7}$ Some of the Chinese incised inscriptions were described above in the section dealing with ceramics.

The ink inscriptions are of special interest because they are written using three different writing systems: Chinese, Arabic, and Indic scripts. A total of 438 shards with ink inscriptions were identified, among which 201 bear Indic scripts, 27 bear Arabic scripts, and 19 bear Chinese characters. At present, the script-type on 191 shards cannot be identified, as they are too fragmentary. These ink inscriptions mainly appear around and on the base of the unglazed jars and dishes. Some of the dishes may have been used as lids. Each shard appears to contain only one type of script. As for the content of the inscriptions, the Arabic texts appear to be a Muslim religious formula containing the name of the prophet, whereas the Indic texts apparently consist of various single words and the Chinese texts consist of one or two characters each. Although ink inscriptions on ceramic shards were also found in the Belitung shipwreck, they are not texts but Buddhist symbols. ${ }^{8}$ Thus, the ink inscriptions from the Chau Tan shipwreck material might be some of the oldest extant specimens of ink inscriptions in Arabic and Indic scripts.

The Indic script used on the shards from the Chau Tan shipwreck has been identified as a Southern Brahmic script originating from the Southern Brāhmī script, although it is possible that one of the inscriptions was written in a Northern Indic script. The Southern Brahmic script was extensively used in South and Southeast Asia, with a range of regional and historical variations. Some of the better-known varieties include the Pallava script developed in South India and the Kawi script in Java and other parts of Island Southeast Asia. Although further epigraphical studies are needed to determine the precise characteristics of the Indic scripts found in the Chau Tan shipwreck, a comparison with the Kawi script - whose chronological development is relatively well established - suggests that these Indic scripts correspond to the archaic phase of the Early Kawi script (ca. $750-850 \mathrm{CE}$ ) and the standard form of the Early Kawi script (ca. 850-925 CE)..$^{9}$ This dating is, in turn, consistent with the results obtained from the radiocarbon dating of the salvaged ship timbers and comparative study of the salvaged ceramics.

7 John Guy, "Rare and Strange Goods: International Trade in Ninth-Century Asia," in Shipwrecked: Tang Treasures and Monsoon Winds, ed. Regina Krahl et al. (Washington, DC: Smithsonian Institution, 2011), 21, 26.

8 Yang Liu, "Tang Dynasty Changsha Ceramics," in Krahl et al., Shipwrecked, 155.

9 J. G. de Casparis, Indonesian Palaeography: A History of Writing in Indonesia from the Beginnings to c. A.D. 1500 (Leiden: E. J. Brill, 1975). Specimens of relevant scripts can be found in K. F. Holle, Tabel van Oud- en Nieuw-Indische alphabetten (Batavia: W. Bruining, 1882). 


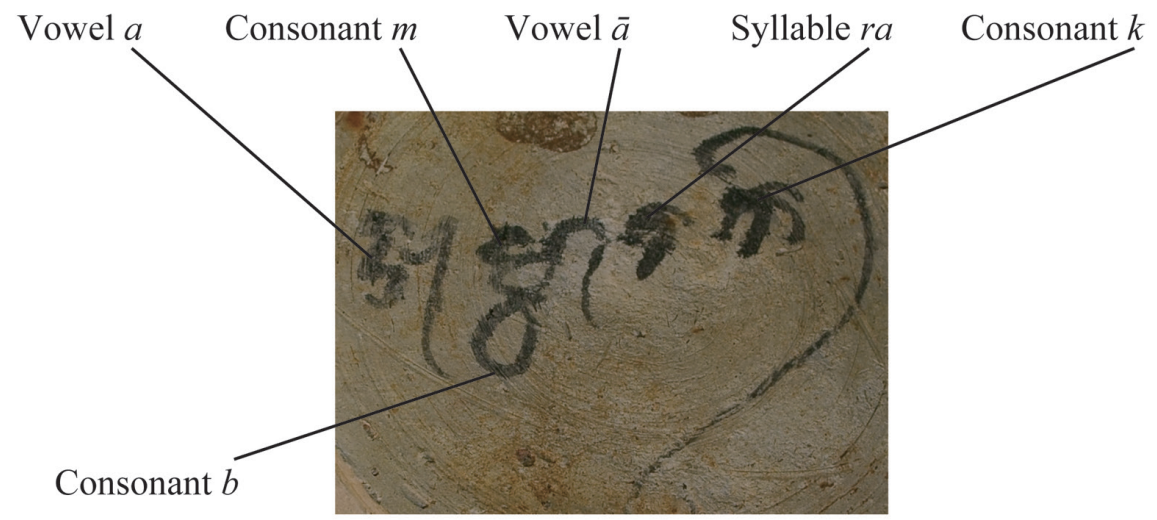

FIGURE 7 Ambārak written in Southern Brahmic script. PHOTO: TORU AOYAMA.

It must also be noted that one specimen on a shard shows a horizontal line above the inscription, a characteristic of the Northern Brahmic script. Further investigation may lead to a better understanding of the origins of such features in these scripts. The Indic script may represent any language in South or Southeast Asia. Since the only word positively identified so far is a place name, to be discussed shortly, it is still too early to determine which language or languages are represented by these Indic scripts.

Several words or word-like phrases have been identified among the 201 shards with Indic scripts: Ambārak, Malyāra (or Maliāra), Ngayampalo (or Ngayangpalo), Manu, and Gupala. The most interesting word among these is Ambārak, which appears on 34 specimens (Fig. 7). As some of the specimens are still complete, this reading appears to be reliable. The handwriting of the scripts seems to be confident, indicating the writer's skill in writing the Indic script. The word Ambārak corresponds to two place names in modern Iran: one in Bushehr Province ( $\left.28^{\circ} 51^{\prime} 01^{\prime \prime} \mathrm{N} 51^{\circ} 11^{\prime} 30^{\prime \prime} \mathrm{E}\right)$ and the other in Kerman Province $\left(28^{\circ} 38^{\prime} 39^{\prime \prime} \mathrm{N} 58^{\circ} 07^{\prime} 29^{\prime \prime} \mathrm{E}\right)$ (Fig. 8). These place names are sometimes spelled as Anbārak. However, as a nasal /n/ before the consonant /b/ regularly changes to $/ \mathrm{m} /$, Ambārak and Anbārak can be regarded as orthographic variants. In a historical context, Ambārak in Bushehr Province is particularly interesting, because the coast of the Persian Gulf is less than $20 \mathrm{~km}$ away; more significantly, the famous port city of Sīrāf-where Tang ceramics have been excavated ${ }^{10}$ - was located $170 \mathrm{~km}$ southeast from there. If the identification of the word Ambārak found in the Chau Tan shipwreck material with the place

10 Regina Krahl, “Green Wares of Southern China," in Krahl et al., Shipwrecked, 187. 


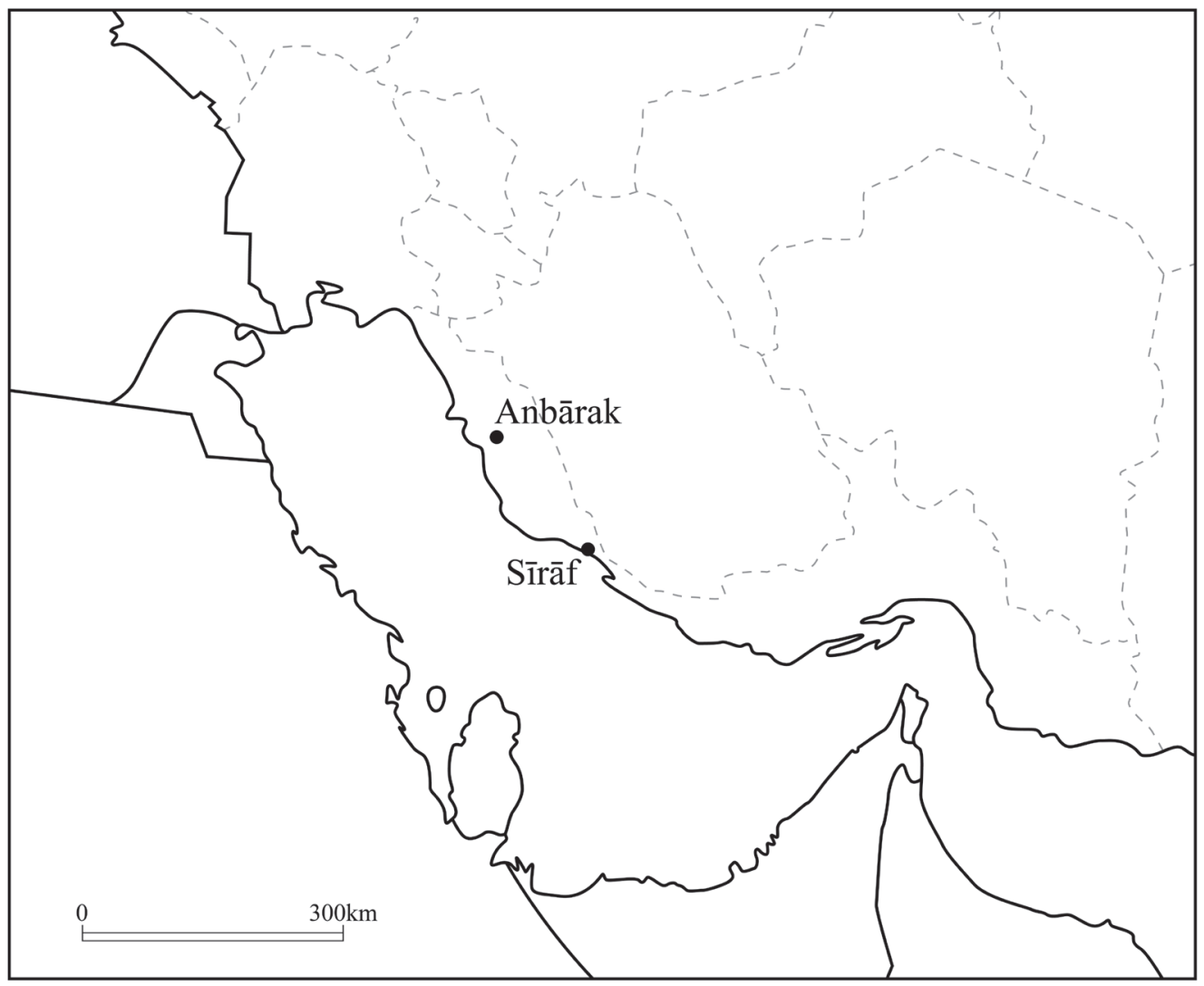

FIGURE 8 Anbarak in Bushehr Province, Iran. IMAGE: GOOGLE EARTH.

name Ambārak in Bushehr Province is correct, this significantly contributes to our understanding of long-distance maritime trade between the Tang and the Indian Ocean world in the ninth century.

The case of Ambārak suggests that at least some of the words in the Indic script may be the names of places where the goods contained in the jar were to be delivered. The jar bearing the word Ambārak in ink may have been scheduled to be sent first to the port of Sirāf and then carried by caravan traders to inland Ambārak. This possibility opens up a wide range of new investigations: for example, the extent to which the use of the Indic script for commercial purposes spread in ninth-century Southeast Asia, the origins (India or Southeast Asia) and occupations (trader, ship crew, or official) of those who wrote the Indic scripts, and their relationship with those who used the Arabic and 
Chinese scripts. Further investigation, in conjunction with research on ceramics, ship timbers, and historical records, will hopefully clarify these questions.

\section{Discussion and Conclusion}

The study of the Chau Tan shipwreck material initiated by Dr. Masanari Nishimura continues, motivated by an understanding of the importance of his pioneering work and the significance of this ship. Future research faces the difficulties and dilemmas of dealing with salvaged artifacts in a context where salvage operations are still ongoing. In the waters off the sandy beach next to Chau Tan village, the remains of unidentified shipwrecks are being raised without archaeological recording. The situation reflects current government policies and attitudes toward the protection of shipwrecks in the country, which have shown little progress since 1990, when the Con Dao (Vung Tau) shipwreck was salvaged and the artifacts sold at auction and dispersed. The current research group is working closely together with young and senior researchers of the Vietnamese Archaeological Institute to enhance capacity-building in the scientific study of shipwreck material. The study of the Chau Tan shipwreck material is intended to promote the protection of the submerged cultural heritage in the nation's waters by demonstrating the shipwreck's value as a historical resource.

Based on our preliminary study, the ship timbers and the assemblage of salvaged ceramics can tentatively be correlated in time, taking into consideration the fact that more than one ship dating back to the period between the Tang Dynasty and the Five Dynasties was wrecked in such a small area. Further examination is essential to determine the nature of the salvaged objects. The assemblage of salvaged artifacts is similar to those recovered from the ninthcentury Belitung shipwreck found in Indonesia. The two ships voyaged in the South China Sea during the heyday of long-distance maritime trade. The Chau Tan shipwreck material serves as evidence of an ancient maritime connection along the Vietnamese coast between China and the Indian Ocean world, and further scientific studies of the ship may reveal how Vietnamese societies and polities engaged in this long-distance maritime trade.

\section{Acknowledgments}

This project is financially supported by the Mitsubishi Foundation and the Gerda Henkel Foundation. The following research institutes in Japan provided 
generous support for artifact analysis: the Conservation Science Section of the National Research Institute for Cultural Properties, and Kyushu National Museum. We would like to express our gratitude to the following individuals who supported research and fieldwork: Lam Du Xenh, Tanaka Katsuko, Bui Van Hieu, Dinh Thanh Nga, Kevin Edwards, and Ian McCann. 